\title{
LEGAL PROBLEMS IN TAXING INCOME FROM GOVERNMENTAL SECURITIES
}

\author{
ELYIRR E. RouzLR*
}

President Roosevelt, in his message to Congress of April 25, 1938, and again on January 19, 1939, urged Congress to tax the interest from future issues of state bonds, and to authorize the states to tax the interest from future issues of federal bonds. The conflicting reactions to the constitutionality of this proposal are evidenced by the fact that the Department of Justice ${ }^{2}$ and the Joint Committee on Internal Revenue Taxation, ${ }^{3}$ after making comprehensive studies of the subject and examining the same cases, came to opposite conclusions.

\section{The Doctrine of Intergovernaiental Imanunitues}

The legal difficulties with respect to the taxation of the interest from governmental securities arise from the doctrine of intergovernmental immunities. That doctrine, the outgrowth of McCulloch v. Maryland, which found a federal immunity from state taxation, and Collector v. Day, which found a similar immunity for the states from federal taxation, forbids the taxation of one government by the other where the imposition of the tax would tend to interfere with a governmental function of the former. The cases dealing with the immunity are so numerous, and the doctrine has so many refinements, ${ }^{b}$ that its development cannot be retraced in detail within the confines of a brief article. Broadly stated, the law is settled that immunity exists only when the government is acting in a governmental, as opposed to a proprietary, capacity. In addition, where the tax is not imposed directly upon the state or federal sovereign, it must be shown that the burden of the tax will be passed along to the government.

In order to sustain a tax on the interest from governmental securities it would seem, then, to be necessary to find that the issuance of securities is not a governmental

- A.B. I938, Duke University. Member of the third-year class, Duke Univ. School of Law. Member, editorial board, Duke Bor Ass'a Jowmal.

1 The question of the constitutionality of such a tax cannot be raised under existing tax laws. Federal statutes, state constitutions, statutes and regulations forbid the taxation of the interest of the securities issued by the other government.

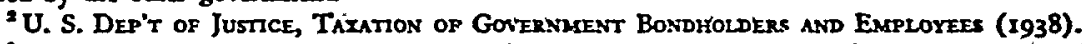

- Report to the Joint Committe on Internal Revenue Taxation, Poxuer of Congress to Tax the Interest from State and Local Securities and the Compensation of State and Local Employees (x939).

4 Wheat. 316 (U. S. 1819 ).

ir Wall. 113 (U. S. 1870).

- See the works cited supra, notes 2 and 3. For shorter treatments see Wenchell, Federad-State Reciprocal Taxation of Income from Public Securities (1939) 17 TAxEs 507, and Brown, Intergovernmental Tax Immunity: Do We Need a Constitutional Amendment? (1940) 25 Wast. L. Rev. 153. 
function, or, that the taxation of the interest from such socurities would not unduly burden the borrowing sovereign. There is little doubt that the issuance of securities is a governmental function. This has been traditionally assumed with respect to the states, ${ }^{7}$ and Mr. Justice Stone, in Graves $\nu . O^{\prime} K_{e} e f e^{8}$ said that every enterprise in which the federal government could constitutionally participate is governmental in nature.

The most compelling argument against the taxation of the interest from taxexempt bonds is that the imposition of the tax would place a real burden on the issuing government. Since the legal incidence of the income tax is upon the individual bondholder, unless he shifis the burden of the tax along to the government, the argument that the tax interferes with a governmental function must fail. But it has been assumed that the burden would be shifed, and that the government would be forced to pay higher interest rates.

From a legal point of view, the most serious obstacle to such a tax may be the famous Pollock case. That case, which declared invalid the income tax law of 1893 , is one of the most disputed decisions of American law. It apparently held three things: ( $I$ ) that, for the purpose of deciding whether an income tax is a direct tax within the meaning of the Constitution, the source of the income must be looked to; (2) that a tax upon the income from real or personal property is a direct tax and has to be apportioned, while a tax on the income from a business or profession is an excise tax and does not have to be apportioned; and (3) that a tax on the interest from state and municipal bonds is invalid. Whether the tax as to interest from bonds was held bad because it was direct and not apportioned or because it was considered a burden on the power of the state to borrow has never been agreed upon. Acceptance of the former view would mean, of course, that the defect was cured by the adoption of the I6th Amendment. However, a very persuasive argument is made that, although four justices dissented from the view that a tax on the income from personal property was invalid because direct, yet the Court unanimously agreed on the invalidity of the tax on the interest from state bonds, and, therefore, the ground of decision on the latter point must have been the effect of the tax as a clog on the power of the government to borrow.

But conceding, as must be done in the light of language in subsequent decisions, that the tax on interest was held bad because it interfered with the borrowing power of the state, ${ }^{10}$ it is not at all sure that the present Court would reaffirm that view.

\footnotetext{
'Howerer, conceivably, a state might not be acting in a governmental capacity when it issues bonds for a proprietary purpose. For instance, the taxation of bonds issued by the state for the purpose of running a liquor store might not involve exactly the same questions as the taxation of a bond issued for the purpose of constructing a courthouse. But, if the tax on income from bonds issued for the former purpose increased the interest rate required, the fiseal effect on the issuing government would seem the same as if the ax had been imposed on income from bonds issued for the latter purpose.

306 U. S. 466 (1939).

- Pollocir v. Farmers' Loan \& Trust Co, 158 U. S. 601 (1895).

${ }^{10}$ The tax could have been held bad because it was 2 direct burden on the state, or because it was shifed from the taxpayer to the state. Taken literally, the Pollock case seems to hold that an income 22 is 2 direct tax on the source of the income, bence that the tax vias the same as a tax an the bonds themselves, which would admittedly be bed. But that the Pollock case has not been followed literally it
} 
Decisions in two related fields have made reasonable the questioning of the force of the Pollock case today. It was held in Helvering $v$. Mountain Producers Corp. ${ }^{11}$ that the income of a government lessee could be taxed. A federal income tax on the salary of an employee of the New York Port Authority, a state agency, was sustained in Helvering $v$. Gerhardt, ${ }^{12}$ and a state tax on the salary of an officer of the Home Owners Loan Corporation, a federal agency, was upheld in Graves v. O'Keefe.13 These cases, on which are based the chief hopes of the advocates of the President's proposal, do indicate a new trend in the Court's attitude toward the doctrine of intergovernmental immunities. Whereas it was formerly presumed that the burden imposed on a governmental lessee or a governmental employee would be passed along to the government, the Court has now indicated that it will examine the particular case to see if the burden actually is shifted. It seems to be required now that it be affirmatively shown that the burden of the tax will be shifted from the individual taxpayer to the government. The fact that the Court found no proof that the burden of the tax had been shifted in the above cases does not preclude the possibility that it will find that a shifting in the ease of taxation of interest from government bonds. But the cases do demonstrate that the Court will actually examine the situation and will no longer assume, without proof, that the tax will be shifted. While there is better evidence that the tax on interest is shifted to the borrower than that the tax on an employee is shifted to the employer, whether there is enough evidence to satisfy the Court that an immunity should be accorded is purely speculative. The economic arguments on both sides are presented in the preceding articles and need not be repeated here.

The President's proposal conceives of a waiver of whatever right to immunity the federal bonds have. That such a waiver would be valid is quite clear. ${ }^{14}$ In the absence of such a waiver a federal tax might succeed where a state tax would fail. It was pointed out in Helvering v. Gerhardt that the immunities of the two governments are not identical; that the federal government is entitled to greater protection through immunity than is the state. This distinction is apparent in at least two forms. First, all functions of the federal government are governmental in nature, while the state may engage in a proprietary function. It is doubtful, as has been seen, whether

evidenced by Peck \& Co. v. Lowe, 247 U. S. 165 (1918), which sustained a tax on profits derived from an exporting business, although the business itself could not have been taxed. New York ex rel. Cohn $\mathbf{~}$. Graves, 300 U. S. 308 (1937), upheld a New York income tax on income derived from property outside the state. It was there pointed out that the Follock case decided only that the income tax was so similar ta a direct tax, when the question was whether apportionment would be required, that it would have to be apportioned. That view was reaffirmed in Hale v. State Board of Assessment, 302 U. S. 95 (I937), which indicated that, apart from the question of apportionment, the income tax might reasonably be regarded as an excise. It follows from these decisions that an income tax on the interest from bonds is not a direct tax on the bonds themselves, and that an immunity will be required only if the burden initially on the bondholder is passed along to the government.

12303 U. S. 376 (1937).

12304 U. S. 405 (1938).

23 Supra note 7.

"Van Allen v. The Assessors, 3 Wall. 573 (1865); Baltimore National Bank v. State Tax Commission, 297 U. S. 209 (1936). And see Mr. Justice Roberts, dissenting, in James v. Dravo Contracting Co. 362 U.S. 134, 181 (1937) where he admits, "No one denics the competence of Congress to waive the immunity in whole or in part." 
this distinction is pertinent in the caso of issuance of securities. Secondly, the federal government has the power to immunize its agencies, ${ }^{15}$ while the state apparently has no corresponding power. In the absence of any expression of Congressional intent, however, the immunity to be afforded interest from federal bonds would be one of implication, and would stand on a parity with the immunity afforded interest from state bonds. ${ }^{10}$

\section{The Effect of the Sixteenth AMendment}

There is another ground on which the immunity now given interest from governmental securities might be removed. The I6th Amendment gives Congress the power to tax income "from whatever source derived" without the necessity of apportionment. The conventional view, and the one to which the Court has adhered, ${ }^{17}$ is that the Amendment gave Congress no new power to tax but merely relieved it from the duty of apportioning a tax on the income from real and personal propertya task which, as has been pointed out, was imposed by the Pollock case.

It is argued by Mr. Justice Black, in his concurring opinion in Helvering v. Gerhardt, ${ }^{18}$ that the words "from whatever source derived" should be given their full force and meaning, and that Congress should be empowered to tax any income without regard to its source. This contention is based on the theory that the 16th Amendment was passed to overcome the effect of the Pollock case and, since that case held invalid a tax on the interest from state bonds, the Amendment. was meant to correct that holding of the case also. Fortifying Mr. Justice Black's position is a mass of material presented by the Department of Justice, ${ }^{19}$ tending, so the Department claims, to show that it was generally believed at the time of ratification that the Amendment would authorize the taxation of the interest from tax-exempt bonds. While such an argument is not irrelevant, it may be attacked as proving too much, for under such an interpretation the income of the state government itself could be taxed, regardless of the burden imposed. Another objection to such a view is that it is inapplicable to the states, and would not give them an equal opportunity to tax. It seems unlikely, in view of its steadfast holdings to the contrary, that the Court will now re-examine the evidence and construe the r6th Amendment to give Congress the power to tax all income, with no regard to source.

\section{Counter Proposals}

Several suggestions have been put forward which would reach the same result as outright taxation of interest from governmental securities, or which would tend to alleviate some of the alleged unfairnesses of the present system. One writer suggests that the tax law be amended so that the tax becomes an "excise on the act and

${ }^{25}$ Pittman v. Home Owners' Loan Corp., 308 U. S. 15 (1939).

${ }^{10}$ Since the immunities of the two governments are not identical, whether the states adopt the proposed tax policy apparently has no bearing on the validity of the proposed federal tax.

${ }^{17}$ Brushaber v. Union Pacific R. R., 240 U. S. I (1916). See Peck \& Co. v. Lowe, 247 U. S. 165, 172 (1918); Metcalf \& Eddy v. Mitchell, 269 U. S. 514, 521 (1926).

${ }^{12} 304$ U. S. 405,424 (1938).

${ }^{20}$ This material is summarized in U. S. Dep'T of Justice, op. cit., supra note 2, Pt. II. 
transaction of receiving income, measured by the net income received." 20 In other words, he proposes to tax the receipt of income, the tax to be measured by the amount of income, including that which is tax-exempt as well as that which is taxable. This plan, as applied to corporations, was sustained in Flint $v$. Stone Tracy Co. ${ }^{21}$

From a practical standpoint, the plan has several points in its favor. . It could be applied by the states as well as the federal government. And it could be applied retroactively. Direct taxation of the interest, as proposed by the President, woyld result in a huge unearned bounty to the present holders of exempt securities unless the tax were imposed retroactively. ${ }^{22}$ The imposition of the tax on the interest from outstanding securities would run into the problem of due process. The taxation of future interest of outstanding governmental securities would not be invalidated by the clause of the Constitution forbidding the impairment of contracts, ${ }^{23}$ for that applies only to the issuing government, but the tax might well be held so arbitrary and unreasonable as to constitute a violation of due process clause: That whole problem would be avoided by imposing an excise tax on the act of receiving income, the tax to be measured by the income.

But the plan is objectionable in that it resorts to a distinction which is of only verbal significance. In result, there is no practical difference between an income tax imposed directly on the interest from governmental bonds and a tax on some privilege when the tax is measured by the same interest. The burden on the borrowing government. would seem to be the same in either case.

It is true that the distinction between subject and measure has been upheld in the cases of a franchise $\operatorname{tax}^{24}$ a tax on the transfer of bonds, ${ }^{25}$ and a tax on profits from their resale. ${ }^{26}$ But in all those cases there was a recognized legal privilege which justified the distinction. The right to incorporate, the right to transfer property upon death, and the right to resell bonds are all privileges accorded by the law. It is by no means clear that there is even a legalistic distinction between the ordinary income tax and a tax on the privilege of receiving income measured by the income. ${ }^{27}$

Two other plans have been advanced which utilize another distinction-that between subject and rate. As early as Igrg Senator Carter Glass suggested that tax exempt income be used to determine the rate to be applied to the taxable income.

${ }^{20}$ Shultz, Tax Exemptions of Governmental Securilies (1939) I7 Taxas 33r.

22220 U. S. 107 (19l1). A state franchise tax measured by exempt federal securities was upheld in Pacific Co. v. Johnson, 258 U. S. $480^{\circ}$ (1932).

${ }^{23}$ It is insisted by the Department of Justice that the tax would be applied only prospectively.

"21 U. S. Const. Art. I, 5 ro. 24 Flint v. Stone Tracy Co., supre note 21.

${ }^{28}$ Greiner v. Lewellyn, 258 U. S. 384 (1922). $\quad 26$ Willeuts v. Bunn, 282 U. S. 216 (193I).

${ }^{27}$ It is not certain, in the light of the Hale case, supra note 10, that the income tax is not now regarded as an excise tax. In that case an Iowa income tax imposed upon the interest of bonds issued tax free by lowa was sustained. The ax was upheld on the grounds that the exemption related only to property taxes and that, for the purpose of deciding whether the imposition of an income tax would impair the state's contract not to tax the bonds, the income tax was reasonably regarded as an excise. The Pollock case was distinguished on the same grounds as it was in the Cohn case, supra note 10. Since the tax was imposed by the same state which issued the bonds no question of burden was involved, but it is not inconceivable that the Court would hold that, for the purpose of determining burden, the income tax was an cxcise. 
This plan has been recently advocated by Mr. Roswell Magill while Under Secretary of the Treasury, ${ }^{28}$ and has been championed, in modified form, by Professor C. $\mathbf{L}$. B. Lowndes. ${ }^{29}$ The Treasury plan, in brief, is to allocate exempt income to the lowest surtax bracket, rather than the highest, for the purpose of determining the rate of tax. A simple example will help. Assume a taxing statute under which income up to $\$ 50,000$ is taxed at $10 \%$, and all over that amount at $20 \%$. $T$, a taxpayer, has a net income of $\$ 100,000$, half of which comes from governmental securities. Under the existing income tax T's exempt income is entirely excluded from computation, with the result that his taxable income of $\$ 50,000$ falls into the lower bracket, producing a tax liability of $\$ 5,000$. The exempt income is, in effect, allocated to the higher bracket, then disregarded. Under the Treasury plan, T's entire income, including that which is tax-exempt, would be considered to establish the rate. The exempt income is allocated to the lower bracket, which pushes the taxable income into the higher bracket. Once the rate is determined, the exempt income is withdrawn, leaving the taxable income suspended in the higher bracket. In the example, T's income would be pushed into the higher bracket, and the tax rate of $20 \%$ would attach. His tax liability, then, would be $\$ 10,000$.

The alternative plan, suggested by Professor Lowndes, would distribute the exempt income in all the brackets rather than place it arbitrarily in the lowest bracket. In the hypothetical case, for instance, half of T's taxable income would be allocated to the $10 \%$ bracket and half to the $20 \%$ bracket. As a result, his taxable income would be taxed at the average rate of tax for a taxable income of the same size as his total income. The specific mechanics of computing such a tax would be to ascertain the tax which would be assessed on 'T's entire income, were it all taxable. That part of the tax which is proportionate to the part of his income which is taxable would be paid to the government. In the illustration, the tax upon an income of $\$ 100,000$ would be $\$ 15,000$. Since half of $T$ 's income is taxable, he would pay half this sum, or $\$ 7,500$.

The obvious objection to these plans is that they tax indirectly what it is assumed cannot be taxed directly. The language of Mr. Justice McReynolds, in National Life Insurance Co. v. United States," looks ominous: "One may not be subjected to a greater tax burden on his taxable property because he owns some that is free." But that passage loses some of its force when it is remembered that the same justice later upheld a tax which provided that interest paid on an indebtedness incurred to purchase or carry tax exempt bonds was not deductible, although all other interest payments. were deductible. ${ }^{31}$ The tax was upheld on the grounds that the provision was "to prevent the escape from taxation of income properly subject thereto by the purchase of exempt securities with borrowed money." It is arguable that the Treas-

\footnotetext{
${ }^{28}$ Magill, The Problem of Intergovernmental Tax Exemption (1937) 15 TAx Magazine 699.

${ }^{20}$ Lowndes, Taxing the Income from Tax Exempt Securities (1938) 32 IL.L. L. Rev. 643; Lowndes, The Fedetal Income Tax and Interest from State and Municipal Bonds (1938) 3 LEGAl Notes on Local GOVERNMENT 345 .

${ }^{30} 277$ U. S. 508, 519. (1928). "Denman v. Slayton, 282 U. S. 514 (1931).
} 
ury plan increases the tax burden only to the extent that it is necessary to prevent undue escape from taxation. ${ }^{32}$

There are two cases in the field of jurisdiction to tax which may have some bearing of the validity of these proposals. Maxwell v. Bugbee $e^{33}$ upheld a New Jersey .inheritance tax computed upon the entire estate of the decedent, including property outside the state and not subject to its jurisdiction. The part of the tax which was proportionate to the New Jersey share of the entire estate was paid to the state. The mechanics were essentially the same as those suggested by Professor Lowndes. Authority for the Treasury proposal is found in Great Atlantic \& Pacific Tea Co.v. Grosjean, ${ }^{34}$ sustaining the Louisiana chain store tax which fixed the rate of tax on stores within the state, not by the number of stores within the state; but by the total number in the chain, both within and without Louisiana.

While it is true that these decisions are not direct authority for the inclusion of tax exempt interest for the purpose of computing rate, because they are in the field of jurisdiction to tax, there is reason for believing that the reasoning is equally applicable to tax exemptions. The Supreme Court has held, in connection with jurisdiction to tax, that extra-territorial property cannot be included in the measure of a death ${ }^{35}$ or franchise tax, ${ }^{36}$ while upholding death taxes measured by exempt securities $^{37}$ and franchise taxes measured by net income from such sources. ${ }^{38}$ This would lead to the conclusion that the policy against extra-territoriality is stronger than the policy against taxing tax-exempt securities. It may follow, then, that since the rate of tax can be determined by extra-territorial property, it can be determined by exempt securities,

Unless justified by some economic consideration, this distinction between subject and rate should be criticized on the same grounds as the distinction between subject and measure. That the Supreme Court is concerned with economic considerations is evidenced by the fact that, while the latter distinction has been upheld in the cases noted above, it has been rejected in others. ${ }^{39}$

In this connection, there should be considered the potential advantages of the Treasury proposal arising from the fact that governmental securities could still be sold at low interest rates since they would be just as attractive to big corporate buyers whose tax rates are not sharply progressive. The system of measuring the rate of tax by exempt securities would not affect a taxpayer who did not pay a progressive tax. And since a large proportion of governmental securities are held by corporations which pay a flat tax, the governmental issues could still compete effectively in the money market. This would meet one of the major objections to the imposition of an outright tax on the interest.

"A taxpayer's average rate of tax is lowered if he owns tax exempt securities. To prevent tax evasion through lowered rates, the exempt interest might reasonably be included to fix the rate.

25 U. S. 525 (1919).

${ }^{25}$ Frick v. Pennsylvania, 268 U. S. 473 (1925).

se Union Refrigerator Transit Co. v. Kentucky, 199 U. S. 194 (1905).

${ }^{27}$ Greiner v. Lewellyn, supra note 25.

s0 Northwestern Mutual Life Insurance Co. v. Wisconsin, 275 U. S. 136 (1927); Macallen Co. v. Mass, 279 U. S. 620 (1929). 
At the same time, the plan would do much to eradicate the unfairness of the present system with regard to individuals, and the divergence from the ability to pay theory which arises when the tax exemption may mean a saving of $79 \%$ to one taxpayer and only $4 \%$ to another. Whether such rise in interest rates as might be expected from the fact that individuals do purchase governmental bonds could be offset by the increased revenues is, of course, conjectural. Finally, this plan would remove the legal objection to applying the direct tax retroactively and thereby eliminate the unearned increment which would result to the holders of governmental securities if the direct tax were applied only prospectively.

From a practical standpoint, an objection to the plan would lie in the fact that the states, with their low income tax rates, could not use it to advantage. Moreover, the plan would not be as productive in revenue, even for the federal government, as direct taxation.

\section{Constitutional Amendment and Interstate Compact}

The short answer to all doubts as to the constitutionality of taxing the interest from governmental securities would be the adoption of a Constitutional amendment. But the delay and the practical difficulties which would be encountered in securing ratification discourage such a step. An amendment requires ratification by three fourths of the states, and since the states would risk revenue losses by its adoption, it is exceedingly doubtful whether the requisite number would approve it. ${ }^{40}$

Another proposal is that the federal government and all the states sign a mutual pact, each permitting the other to tax such interest. Such a plan would be practically impossible to carry out. Absolute mutuality could not be achieved until the sixteen states which do not have income tax laws at the present time enacted them. It would then be necessary that every state sign the agreement, a requirement more rigorous than that for the passage of a Constitutional amendment, and just that much harder to achieve.

10 That this fear is not unfounded is proved by the fact that the governors of all the states and the mayors of the principal cities in the country have banded together to fight any scheme which might result in the taxation of the interest from state and local securities. See Betters, The Proposal to Tex Income from Goveromental Securities: II. The Case Against Taxation, supra, at p. 222. 